\title{
Sistem Informasi Geografis Penyidikan Epidemiologi Jentik Nyamuk Berbasis Android
}

\author{
Firda Liana Muslih ${ }^{1)}$, Jullend Gatc ${ }^{2)}$ \\ Sistem Informasi, Institut Teknologi dan Bisnis Kalbis \\ Jalan Pulomas Selatan Kav. 22, Jakarta 13210 \\ 1) Email: firdaliana13@gmail.com \\ 2)Email: jullend.gatc@kalbis.ac.id
}

\begin{abstract}
Activities Investigation of Epidemiology mosquito larva conducted by UPTD Public health center Wisma Jaya, is an attempt early eradication of Mosquito Nest as the prevention of dengue virus that is transmitted through the Aedes Aegypty mosquito and Aedes Albopictus. Jumantik agent visiting houses of residents to check the existence of larva and recorded the recapitulation of PE. But the process of collecting data PE conducted currently overdue so that the data is not processed in real time to determine the number of free Larva quickly. This research aims to build a geographic information system investigation of epidemiology of mosquito larva-based Android. The design of the system on this research method using Prototyping, modeling system using the Unified Modelling Language and built using Android software Studio. The results of this research is a system for real time collect data of mosquito larvae.
\end{abstract}

Keywords: Android, PE, Prototyping, UML

Abstrak: Kegiatan penyidikan epidemiologi (PE) jentik nyamuk yang dilakukan oleh UPTD Puskesmas Wisma Jaya, merupakan upaya dini Pemberantasan Sarang Nyamuk (PSN) sebagai pencegahan virus dengue yang ditularkan melalui nyamuk Aedes Aegypty dan Aedes Albopictus. Kader jumantik mengunjungi rumah-rumah warga untuk memeriksa keberadaan jentik dan dicatat sebagai rekapitulasi PE. Namun proses pengumpulan data PE yang dilakukan saat ini masih cukup panjang sehingga data tidak diproses secara real time untuk menentukan Angka Bebas Jentik (ABJ) secara cepat. Penelitian ini bertujuan untuk membangun sebuah sistem informasi geografis penyidikan epidemiologi jentik nyamuk berbasis android. Perancangan sistem pada penelitian ini menggunakan metode Prototyping, pemodelan sistem menggunakan Unified Modelling Language (UML) dan dibangun menggunakan software Android Studio. Hasil dari penelitian ini adalah sistem pengumpulan data secara real time terhadap jentik nyamuk.

Kata kunci: Android, PE, Prototyping, UML

\section{PENDAHULUAN}

Demam dengue atau yang biasa disebut dengan demam berdarah adalah penyakit yang disebabkan oleh virus dengue, penyebaran virus terjadi melalui gigitan nyamuk Aedes Aegypti dan Aedes albopictus yang banyak berkembang biak di negara subtropis dan tropis termasuk Indonesia. Penyakit demam dengue dapat menyerang anak-anak hingga orang dewasa. Dalam dua tahun terakhir kasus Demam Berdarah Dengue (DBD) yang terjadi di Kota Bekasi mengalami peningkatan. Salah satu contonya adalah banyaknya pasien DBD yang dirawat menurut diagnosa di RSUD Kota Bekasi pada tahun 2016 sebanyak 978 jumlah kasus [1].

Kegiatan Pemberantasan Sarang Nyamuk (PSN) merupakan upaya pemerintah untuk melakukan pencegahan dini perkembangan nyamuk Aedes aegypty dan Aedes albopictus. Salah satu PSN yang dilakukan oleh UPTD Puskesmas Wisma Jaya adalah dengan melakukan kegiatan PE (Penyidikan Epidemiologi) pemantauan jentik-jentik nyamuk. UPTD Puskesmas Wisma Jaya memiliki dua jenis kegiatan PE, yaitu penyidikan jentik berkala (PJB) merupakan kegiatan rutin yang dilakukan setiap 3 bulan sekali dan jika adanya laporan kasus penderita demam dengue yang memiliki alamat di kelurahan Bekasi Jaya dari rumah sakit atau unit pelayanan kesahatan lain.

Saat ini kegiatan PE di UPTD Puskesmas Wisma Jaya masih bersifat konvensional dimana para kader jumantik yang merupakan tenaga sukarela yang dipilih oleh puskesmas untuk berkeliling ke rumahrumah warga membantu memeriksa jentik-jentik nyamuk. Selanjutnya hasil rekapitulasi penyidikan dicatat pada lembaran form yang selanjutnya diberikan kepada puskesmas. Seringkali data hasil penyidikan mengalami keterlambatan sehingga 
petugas yang bertugas tidak dapat membuat rencana tindak lanjut PSN selanjutnya dengan cepat. Dampak yang dapat ditimbulkan jika kegiatan PSN tidak segera dilaksanakan adalah apabila ditemukan jentikjentik nyamuk di rumah warga, jentik tersebut akan dengan cepat berubah menjadi nyamuk dewasa ketika terendam dalam penampungan air dan menimbulkan penderita baru.

Pemanfaatan teknologi dapat menjadi solusi untuk membantu permasalahan yang terjadi, sehingga dapat meningkatkan kinerja para kader jumantik dan petugas puskesmas untuk menjalankan tugasnya. Pemanfaatan teknologi yang dapat menjadi solusi adalah dengan menggunakan perangkat smartphone Android. Saat ini perangkat tersebut digunakan hampir untuk semua kalangan masyarakat. Penggunaan smartphone juga lebih praktis untuk melakukan pengumpulan data ketika melakukan $\mathrm{PE}$ di lapangan.

Selain itu perangkat smartphone juga dimanfaatkan untuk pengembangan Sistem Informasi Geografis (SIG) karena dilengkapi dengan GPS (Global Positioning System) untuk menentukan letak yang ada dipermukaan bumi. Sehingga data hasil penyidikan tersebut dilengkapi dengan data koordinat/lokasi yang berguna untuk petugas puskesmas sebagai acuan untuk menentukan area endemik jentik nyamuk.

\section{METODE PENELITIAN}

\section{A. Penyidikan Epidemiologi (PE)}

Pemantauan jentik adalah kegiatan pencarian penderita DBD atau tersangka infeksi dengue lainnya dan pemeriksaan jentik nyamuk penular DBD di tempat tinggal penderita dan rumah/bangunan sekitar, termasuk tempat umum dalam radius sekurangkurangnya 100 meter. Pemantauan jentik dilakukan oleh petugas pemantau jentik (jumantik), jumantik yang bertugas memeriksa tempat-tempat yang dianggap menjadi tempat yang memiliki potensi perkembangan jentik.

\section{B. Sistem Informasi Geografis}

Sistem Informasi Geografis (SIG) adalah sebuah sistem yang digunakan untuk memperoleh, memanipulasi dan menyimpan informasi yang berkaitan dengan unsur geografis atau keruangan. Informasi geografis merupakan informasi mengenai lokasi suatu objek atau fenomena yang ada dipermukaan bumi serta atribut pendukungnya [3].

\section{Android}

Android merupakan sistem operasi untuk perangkat mobile yang di akuisisi oleh Google pada tahun 2000. Pada saat itu OS android dikembangkan hanya untuk kebutuhan internal oleh Google dan belum berlisensi open source. Hingga pada 05 November 2007 dirilis perdana dengan standar open source, dengan tujuan untuk mempermudah user dalam mengakses layanan Google. Selain itu android dimanfaatkan oleh Google sebagai media baru penayangan iklan yang dapat menambah pendapatan Google [4].

\section{Android SDK}

Android SDK berfungsi untuk memulai pengembangan aplikasi pada android menggunakan bahasa pemrograman java, selain itu android SDK juga berfungsi sebagai application manager untuk mengunduh, merubah atau menghapus package dan menyediakan menu konfigurasi pembuatan AVD (Android Virtual Device) [4].

\section{E. Android Studio}

Android studio merupakan Integrated Development Environment (IDE) untuk pengembangan aplikasi android berdasarkan IntelliJ IDEA. Android studio memberikan fitur yang lebih banyak untuk meningkatkan produktifitas saat membuat aplikasi android [5].

\section{F. Entity Relationship Diagram (ERD)}

Pemodelan basis data yang paling banyak digunakan adalah entity relationship diagram (ERD). Digunakan sebagai pemodelan basis data relasional, dan dikembangkan berdasarkan teori himpunan matematika. ERD memiliki aliran notasi, berikut ini simbol-simbol yang digunakan dalam ERD [6].

\section{F. Prototyping}

Prototyping merupakan teknik pengembangan sistem yang menyediakan prototype atau gambaran sistem yang akan dibuat. Prototype dibuat oleh pengembang seperti perangkat lunak yang siap digunakan. Selanjutnya prototype tersebut dievaluasi sehingga mendapatkan spesifikasi yang sesuai dengan kebutuhan pengguna. Metode prototyping cocok dipilih oleh pengembang yang akan membangun sebuah perangkat lunak apabila pengguna akhir kurang memahami hal-hal teknis dan kebutuhan yang diberikan tidak spesifik [7]. Gambar 1 menjelaskan tahapan yang terdapat pada pengembangan prototype: 


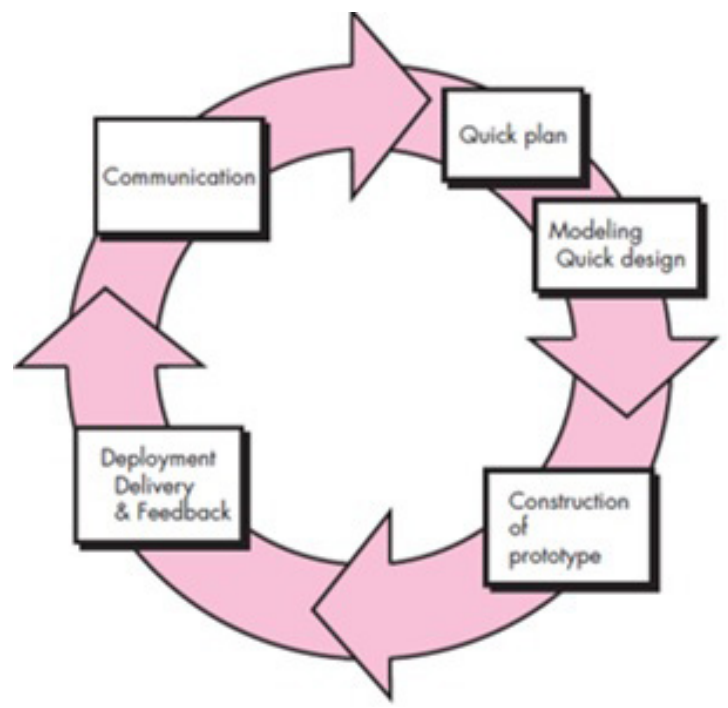

Gambar 1 Tahapan metode prototyping [7]

DariGambar 1 diperoleh:Communication:proses prototype dimulai dengan melakukan komunikasi dengan pengguna. Untuk menentukan tujuan perangkat lunak dan mengidentifikasi persyaratan secara garis besar. Quick plan: perancangan prototype dilakukan secara cepat dan terfokus pada hasil akhir; Modeling quick desain: desain prototype juga dilakukan secara cepat, pembahasan mengenai aspekaspek yang nantinya terdapat pada perangkat lunak seperti desain antar muka dan format hasil output; Construction of prototype: pembuatan perangkat lunak dilakukan berdasarkan perancangan dan desain cepat dilakukan; dan Deployment delivery \& feedback: pengujian perangkat lunak kepada pengguna akhir untuk mengetahui umpan balik mengenai perangkat lunak yang telah dibuat.

\section{G. PHP}

PHP atau hypertext processor merupakan bahasa skrip yang dirancang dalam pengembangan web didalam halaman HTML kode php dapat disisipkan dan dieksekusi oleh server web dan menghasilkan bentuk keluaran berupa halaman html yang dapat dilihat oleh pengguna. Saat ini PHP sudah dikembangkan dan dirilis menjadi versi ke 7.1 dengan beberapa bug keamanan yang telah diperbaiki [9].

\section{H. MySQL}

MySQL adalah perangkat lunak Relational Database Management System (RDBMS) yang bersifat open source berbasis structured query language (SQL). Awalnya MySQL didirikan oleh perusahaan Swedish MySQL AB kemudian diakuisis oleh Sun pada tahun 2008 dan kemudian oleh Oracle pada tahun 2010. MySQL dapat berjalan pada semua platform termasuk linux, UNIX dan windows, sering digunakan untuk pengembangan perangkat lunak berbasis web. MySQL memberikan kemudahan penggunaan dan skalabilitas kepada pengembang untuk mengelola database [9].

\section{Google Maps}

Google Maps merupakan layanan yang disediakan oleh Google yang memberikan informasi secara rinci tentang wilayah geografis berupa peta secara online. Layanan Google Maps memberikan fasilitas yang dapat diakses oleh pengguna untuk mengetahui rute perjalanan secara real time, berbagai tempat dan berbagai Kota di seluruh dunia [10].

\section{J. Google Maps API}

Google Maps API merupakan dokumentasi yang disediakan Google untuk para pengembang yang ingin mengembangkan perangkat lunak dan menyematkan Google Maps kedalam aplikasi. Google Maps API tersedia untuk Android, iOs, web browser dan web Service. API memiliki dua elemen kerja dimana spesifikasi yang menggambarkan bagaimana pertukaran informasi antar program dilakukan dalam bentuk permintaan untuk pengolahan dan pengembalian data yang diperlukan dan yang kedua adalah antarmuka perangkat lunak yang ditulis dengan spesifikasi tersebut diterbitkan dengan cara tertentu untuk digunakan [10]

\section{K. Pengujian Alpha}

Pengujian alpha dilakukan dengan cara, penguna akhir menggunakan aplikasi secara langsung kemudian pengembang mencatat setiap tindakan yang dilakukan oleh pengguna dan mencatat setiap kesalahan yang terjadi selama pengguna menggunakan aplikasi tersebut [11].

\section{Unified Modelling Languange (UML)}

Merupakan standarisasi pemodelan sistem, digunakan untuk merancang dan memvisualisasikan perangkat lunak. Karya Grady Booch, James Rumbaugh, Ivar Jacobson pada tahun 1996, yang akan digunakan untuk desain berorientasi objek, namun sejak itu diperluas untuk mencakup beragam proyek rekayasa perangkat lunak yang lebih luas. UML dapat digunakan secara konsisten di seluruh proses pengembangan perangkat lunak [12].

\section{Desain penelitian}

Kerangka pemikiran adalah cara berpikir peneliti selama melakukan penelitian yang digambarkan berupa alur atau tahapan-tahapan dari awal hingga 
akhir. Kerangka pemikiran yang digunakan pada penelitian ini dapat dilihat pada Gambar 2.

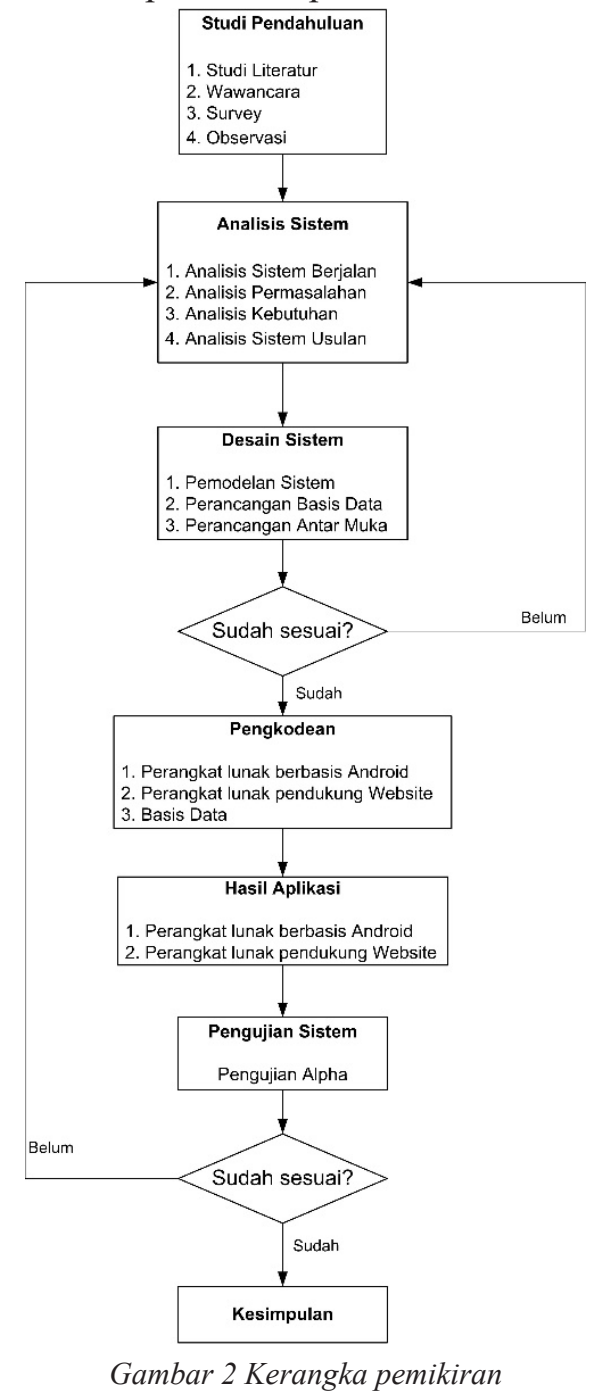

Tahap pertama yang dilakukan adalah studi pendahuluan: Studi Literatur, melakukan studi literatur dengan cara mencari data dan informasi pada situs resmi Badan Pusat Statistik (BPS) Kota Bekasi. Hasil yang diperoleh adalah mendapatkan data banyaknya pasien Demam Berdarah Dengue (DBD) yang dirawat menurut diagnosa di RSUD Kota Bekasi. Selain itu peneliti juga melakukan pencarian buku, prosiding dan jurnal yang berkaitan dengan penelitian yang dilakukan; Wawancara, melakukan wawancara terhadap narasumber yaitu seorang petugas puskesmas yang bertanggung jawab menangani kasus demam berdarah untuk mendapatkan informasi terkait sistem yang sedang berjalan sebagai bahan peneliti untuk melakukan proses analisis permasalahan apa yang terjadi; Observasi, melakukan observasi dengan cara mengikuti salah satu kegiatan PE. Observasi dilakukan untuk mengamati aktivitas PE yang dilakukan dan berinteraksi langsung dengan kader jumantik yang melakukan kegiatan tersebut; dan Survey, melakukan survey dengan cara menyebarkan kuisioner kepada para kader jumantik mengenai perangkat smartphone apa yang digunakan. Hasil survey dijadikan landasan peneliti untuk memberikan solusi sistem seperti apa yang akan dibuat.

Tahap kedua adalah peneliti melakukan analisis sistem yang mencakup analisis sistem berjalan, analisis permasalahan, analisis kebutuhan dan analisis sistem usulan, berikut ini merupakan uraian dari proses analisis: Analisis sistem berjalan, menganalisis keseluruhan sistem yang sedang berjalan pada proses penyidikan epidemiologi jentik nyamuk di UPTD Puskesmas Wisma Jaya. Data diperoleh berdasarkan wawancara yang dilakukan, selanjutnya alat yang digunakan untuk menggambarkannya sistem berjalan tersebut menggunakan flowchart; Analisis permasalahan, merupakan kegiatan untuk menganalisis masalah yang terjadi pada proses kegiatan penyidikan di UPTD Puskesmas Wisma Jaya. Data diperoleh berdasarkan hasil wawancara dengan seorang petugas puskesmas; Analisis kebutuhan, dilakukan untuk menentukan kebutuhan apa saja yang diperlukan untuk pengembangan sistem baru berdasarkan hasil wawancara dengan petugas dan observasi yang dilakukan. Peneliti menentukan dua jenis kebutuhan didalam penelitian ini yaitu analisis kebutuhan fungsional dan nonfungsional; dan Analisis sistem usulan, merupakan proses analisis untuk melakukan pengembangan sistem. Peneliti merancang sistem baru berdasarkan permasalahan yang terjadi dan sebagai usulan penyelesaian masalah.

Tahap ketiga adalah membuat rancangan sistem, peneliti membuat pemodelan sistem, merancang basis data dan merancang tampilan antar muka. Berikut ini merupakan uraian dari desain sistem: Pemodelan sistem, pada tahap ini pemodelan sistem menggunakan Unified Modelling Language (UML). Aplikasi yang digunakan untuk merancang sistem adalah starUML; Pemodelan basis data, dirancang menggunakan Entity Relationship Diagram (ERD); Perancangan antar muka, peneliti membuat rancangan dengan menggunakan aplikasi Balsamiq.

Tahap keempat adalah membangun perangkat lunak. Pengkodean dilakukan menggunakan software Android Studio untuk aplikasi pencatatan data jentik nyamuk, sedangkan aplikasi penunjang untuk petugas puskesmas merupakan aplikasi berbasis web native yang dibangun menggunakan software Sublime text editor dan menggunakan bahasa pemrograman HTML dan PHP.

Tahap kelima adalah melakukan pengujian sistem. Pengujian dilakukan untuk memeriksa seluruh komponen dan fungsi yang ada didalam sistem telah 
layak digunakan. Pengujian sistem didalam penelitian menggunakan teknik pengujian alpha. Perangkat lunak diuji bertujuan untuk mengetahui apakah ada error ketika menjalankan suatu proses.

\section{HASIL DAN PEMBAHASAN}

\section{A. Analisis Sistem Berjalan}

Pada tahap ini peneliti membuat gambaran sistem berjalan. Terdapat dua skenario yaitu sistem berjalan untuk proses PE berdasarkan laporan kasus dan penyidikan jentik berkala.

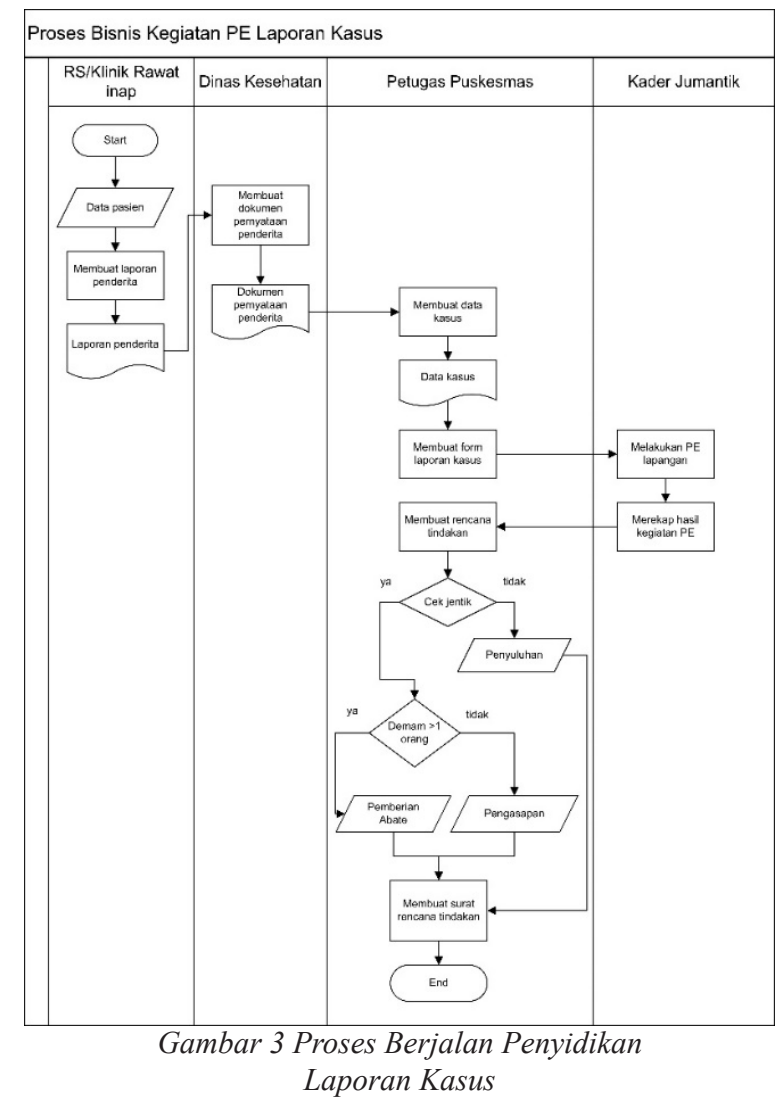

Gambar 3 menjelaskan alur skenario sistem dari penyidikan laporan kasus. Adapun skenario sistem akan dijelaskan sebagai berikut: Rumah sakit membuat laporan pasien penderita $\mathrm{DB} / \mathrm{DD}$ dari data pasien yang positif berdasarkan uji lab. Laporan tersebut diserahkan kepada Dinas Kesehatan Kota Bekasi. Selanjutnya Dinas Kesehatan Kota Bekasi menerima laporan pasien penderita DB dari rumah sakit lalu membuat laporan pernyataan kasus DB/ DD. Laporan pernyataan kasus DB//DD kemudian dikirim ke UPTD Puskesmas Wisma Jaya. Setelah menerima laporan pernyataan kasus DB petugas puskesmas membuat form laporan kasus.; dan Kemudian petugas menginformasikan kepada jumantik untuk melakukan PE ke rumah warga yang menjadi penderita DB/DD. Jumantik melakukan PE untuk memeriksa jentik dan mencatat rekapan hasil kegiatan PE Formulir rekapitulasi hasil PE diperiksa dan dilakukan analisa untuk mengetahui rencana tindak lanjut PSN. Petugas puskesmas membuat surat tindakan hasil PE berdasarkan hasil kegiatan PE.

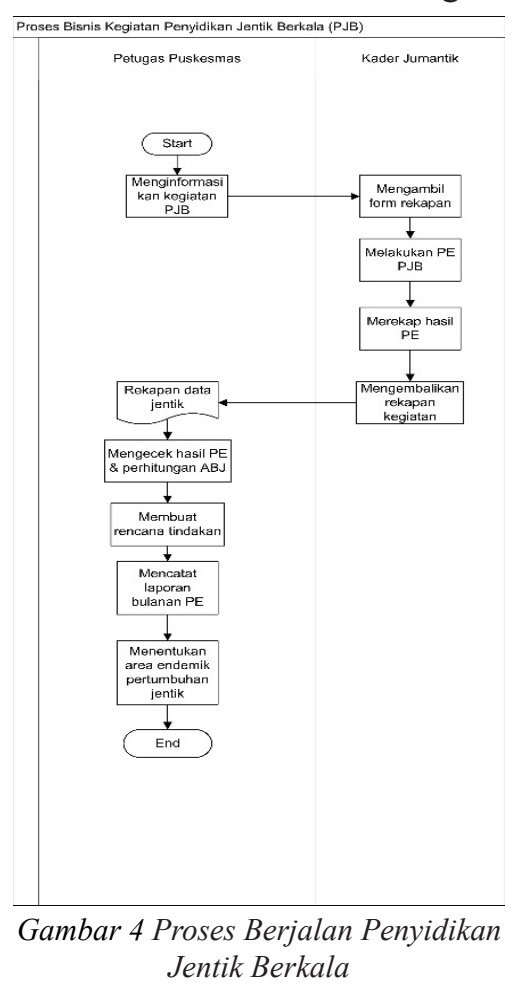

Gambar 4 menjelaskan alur skenario sistem dari proses penyidikan jentik berkala Adapun skenario sistem akan dijelaskan sebagai berikut: Kader jumantik yang merupakan kader posyandu meminta perizinan kepada ketua RT setempat untuk melakukan kunjungan ke rumah-rumah warga bahwa kegiatan pjb akan dilakukan. Petugas melakukan PE di rumah-rumah warga. Selanjutnya petugas puskesmas melakukan pengecekan seperti pada proses PE laporan kasus untuk mengetahui data jentik dan kriteria lainnya. Petugas puskesmas menghitung angka bebas jentik dari hasil rekapitulasi PE; Setelah dilakukan pemeriksaan dan perhitungan petugas membuat rencana tindak lanjut setelah kegiatan pjb. Rencana tindakan berdasarkan rekapan hasil pjb dan perhitungan ABJ; Petugas puskesmas membuat surat tindakan hasil PE kepada RT setempat yang telah dilakukan pemeriksaan jentik yaitu kegiatan pemberantasan sarang nyamuk atau PSN; dan Petugas puskesmas melakukan tindakan PSN berupa penyuluhan atau pemberian bubuk abate atau melakukan pengasapan di area tersebut. Petugas membuat laporan hasil kegiatan PE dan mengumpulkan berkas kegiatan PE menjadi satu.

\section{B. Analisis Permasalahan}

Analisis permasalahan dilakukan untuk menemukan permasalahan berdasarkan hasil wawancara yang dilakukan sebelumnya. terdapat 
beberapa permasalahan yaitu: Proses pencatatan data jentik nyamuk yang dilakukan mengalami waktu yang cukup panjang sehingga petugas puskesmas tidak dengan segera membuat rencana tindak lanjut PSN selanjutnya; Petugas puskesmas juga melakukan perhitungan angka bebas jentik secara manual; dan Penentuan area endemik masih berupa tabel data, idealnya untuk menentukan fenomena di suatu area dapat divisualisasikan menggunakan pemetaan.

\section{Analisis Kebutuhan}

Analisis kebutuhan dilakukan untuk menentukan kebutuhan apa saja yang diperlukan dalam pengembangan sistem baru. Peneliti menentukan dua jenis kebutuhan didalam penelitian ini yaitu analisis kebutuhan fungsional dan nonfungsional.

\section{Analisis Sistem Usulan}

Analisis sistem baru dilakukan untuk menentukan fungsi apa saja yang dibutuhkan untuk pengembangan sistem yang baru dan sebagai usulan untuk penyelesaian masalah. Peneliti menentukan beberapa hal yang menjadi fungsi utama untuk perancangan sistem informasi geografis penyidikan epidemiologi jentik nyamuk berbasis android.

\section{E. Desain Sistem}

Pada tahap ini peneliti melakukan sebuah perancangan terhadap sistem yang akan dibuat dimulai dari pemodelan sistem, perancangan basis data, dan perancangan antarmuka.

\section{Pemodelan Sistem}

Pada fase pemodelan sistem, peneliti melakukan perancangan konseptual menggunakan unified model language (UML). Pemodelan system dibuat berdasarkan dari analisis kebutuhan fungsional yang telah dilakukan sebelumnya. Tujuan pemodelan adalah untuk memodelkan sistem yang akan dirancang sehingga memberikan kemudahan untuk menerjemahkan konsep yang telah dibuat menjadi aplikasi akhir. Perancangan UML ini terdiri dari use case diagram dan activity diagram

\section{Perancangan Antarmuka}

Berikut ini merupakan desain perancangan antarmuka. Sistem ini terdiri dari 2 pengguna utama yaitu kader jumantik dan petugas puskesmas. Untuk kader jumantik akan dirancang sistem berbasis android, sedangkan untuk petugas puskesmas akan dirancang sistem berbasis website.



Gambar 5 Rancangan Tampilan Halaman Login

Gambar 5 merupakan rancangan halaman login, halaman ini merupakan tampilan utama pada aplikasi berbasis mobile. Halaman login digunakan oleh jumantik untuk memulai menjalankan aplikasi. Terdapat edit text yang digunakan untuk memasukan data username dan password jumantik untuk masuk kedalam aplikasi sistem informasi penyidikan jentik. Selanjutnya terdapat satu buah button yang digunakan untuk melakukan proses login dan akan melanjutkan ke halaman utama.

\section{E. Pengkodean}

Setelah proses perancangan desain dan pemograman aplikasi, berikut ini merupakan hasil aplikasi yang didapatkan setelah peneliti melakukan pembangunan perangkat lunak.

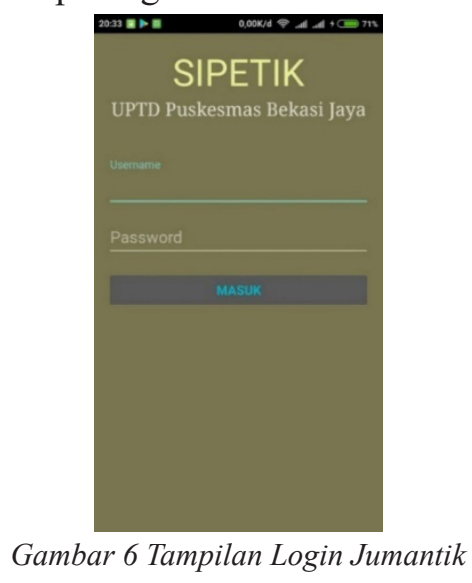

Gambar 6 merupakan halaman login merupakan tampilan awal pada aplikasi. Untuk dapat melakukan login, data kader jumantik sudah dimasukan kedalam sistem pada aplikasi website pendukung yang digunakan oleh petugas puskesmas. Data yang dimasukan berupa data pribadi termasuk username dan password untuk dapat masuk kedalam aplikasi. Kader jumantik mengisi username dan password pada form login, apabila proses login berhasil maka aplikasi akan menampilkan halaman utama. 


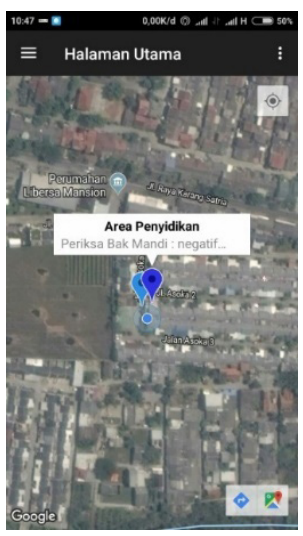

Gambar 7 Tampilan Halaman Utama

Gambar 7 merupakan halaman utama dari aplikasi sistem informasi penyidikan jentik (Sipetik). Halaman ini yang akan muncul ketika kader jumantik telah melakukan proses login. Halaman ini berisi peta yang diakses menggunakan Google Maps, terdapat marker yang menandakan hasil penyidikan di area tersebut. Hasil penyidikan ditampilkan menggunakan marker info.

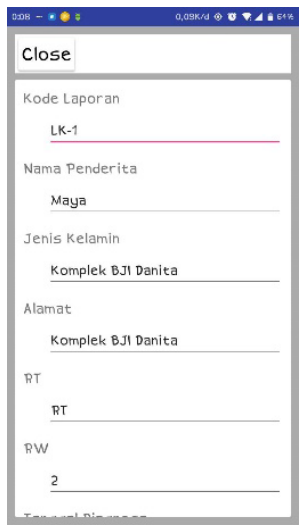

Gambar 8 Tampilan Halaman Laporan

Kasus

Gambar 8 merupakan tampilan dari data laporan kasus. Pada halaman ini berisi data penderita demam berdarah yang diterima oleh petugas puskesmas, selanjutnya petugas membuat data laporan kasus dan dapat diterima oleh kader jumantik. Jumantik melakukan kegiatan PE dirumah yang menjadi penderita demam berdarah. Kader jumantik yang bertugas melakukan PE sesuai dengan lokasi dimana jumantik dan pasien penderita demam berdarah tersebut tinggal. Terdapat button close untuk menutup halaman data laporan kasus, dan kembali ke halaman list laporan kasus.

Gambar 9 merupakan tampilan form input data PE laporan kasus. Pada halaman ini menampilkan form input untuk memasukan data penyidikan laporan kasus. Terdapat button close pada sisi atas form untuk kembali kehalaman sebelumnya. Selanjutnya terdapat button simpan untuk menyimpan data dan button batal untuk membatalkan pengisian data.

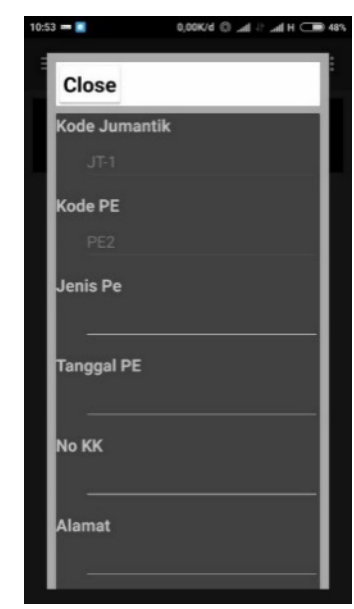

Gambar 9 Tampilan Halaman PE Laporan
Kasus

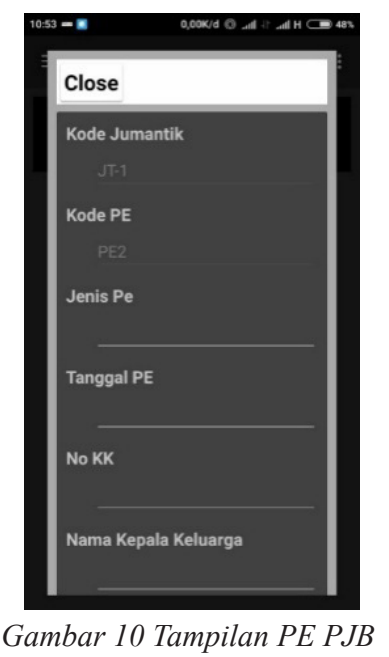

Gambar 10 merupakan tampilan form input data PE PJB. Pada halaman ini menampilkan form input untuk memasukan data penyidikan jentik berkala. Terdapat button close pada sisi atas form untuk kembali kehalaman sebelumnya. Selanjutnya terdapat button simpan untuk menyimpan data dan button batal untuk membatalkan pengisian data.



Gambar 11 Tampilan Input Bangunan yang diperiksa

Gambar 11 merupakan tampilan form input data bangunan yang diperiksa. Pada halaman ini menampilkan form input untuk memasukan data 
jumlah bangunan yang diperiksa dan data bangnan yang negatif jentik. Terdapat button close pada sisi atas form untuk kembali kehalaman sebelumnya. Selanjutnya terdapat button simpan untuk menyimpan data dan button batal untuk membatalkan semua pengisian data.

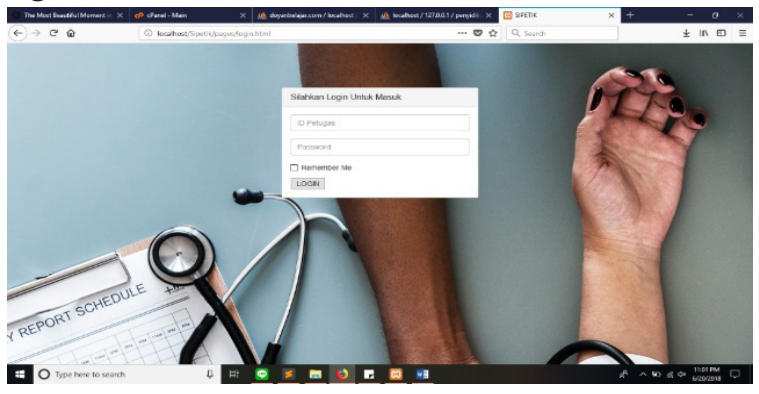

Gambar 12 Tampilan Login Petugas

Gambar 12 merupakan tampilan halaman login pada aplikasi pendukung yang digunakan oleh petugas puskesmas. Pada halaman ini terdapat form input untuk memasukan id petugas dan password. Terdapat button untuk memproses login.

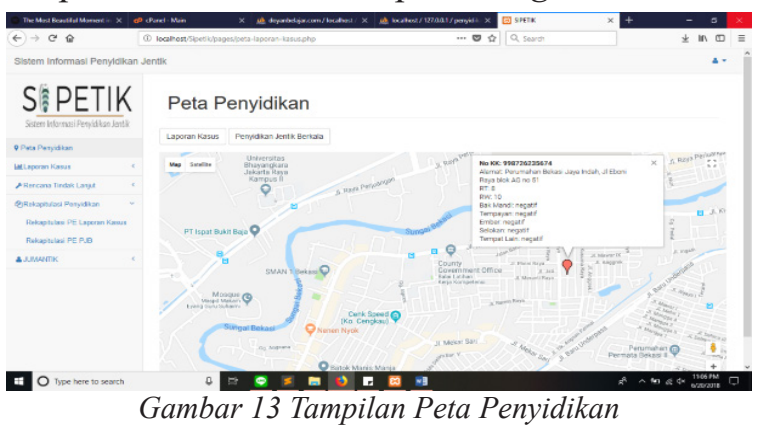

Gambar 13 merupakan tampilan peta penyidikan laporan kasus. Halaman ini menjadi halaman utama yang muncul setelah petugas melakukan proses login. Peta penyidikan laporan kasus menggunakan peta yang diakses menggunakan Google Maps. Terdapat dua tipe peta yang didapat diubah yaitu peta dengan tipe satelit dan peta dengan tipe map. Pada halaman ini terdapat marker yang akan menampilkan marker info hasil penyidikan laporan kasus. Informasi yang ditampilkan berupa No KK, alamat, RT, RW dan hasil pemeriksaan perkembang biakan jentik nyamuk.

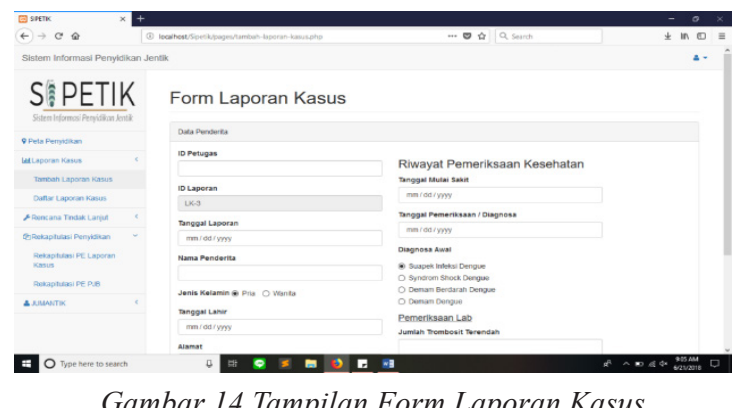

Gambar 14 merupakan tampilan form input data laporan kasus. Halaman ini digunakan oleh petugas puskesmas untuk memasukan data laporan kasus yang diterima oleh puskesmas. Data yang dimasukan berupa data penderita kasus demam berdarah serta riwayat pemeriksaan kesehatan pasien. Terdapat dua button pada halaman form input data laporan kasus, yaitu button simpan untuk menyimpan data laporan kasus dan button batal untuk membatalkan pengisian data laporan kasus.

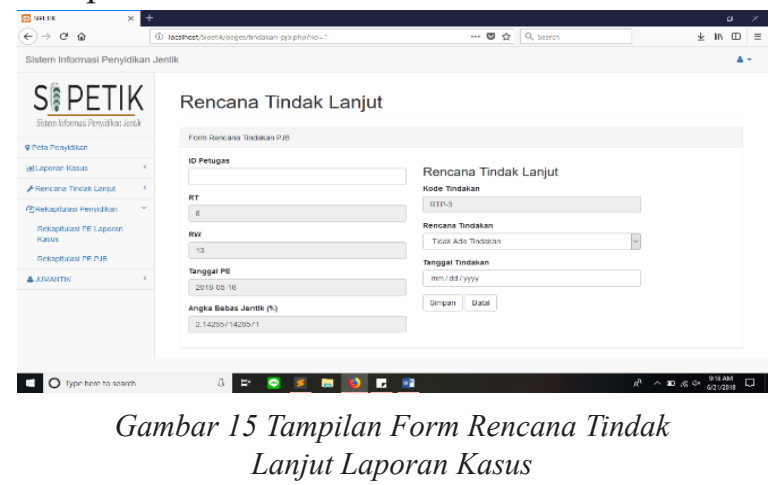

Gambar 15 merupakan tampilan untuk input data rencana tindak lanjut laporan kasus. Pada halaman ini terdapat form input yang akan digunakan oleh petugas puskesmas ketika akan menentukan rencana tindak lanjut hasil penyidikan laporan kasus. Kode PE dan tanggal PE ditampilkan berdasarkan hasil penyidikan laporan kasus yang telah dilakukan oleh jumantik. Terdapat dua button yaitu simpan untuk menyimpan data rencana tindakan dan button batal untuk membatalkan pengisian data.

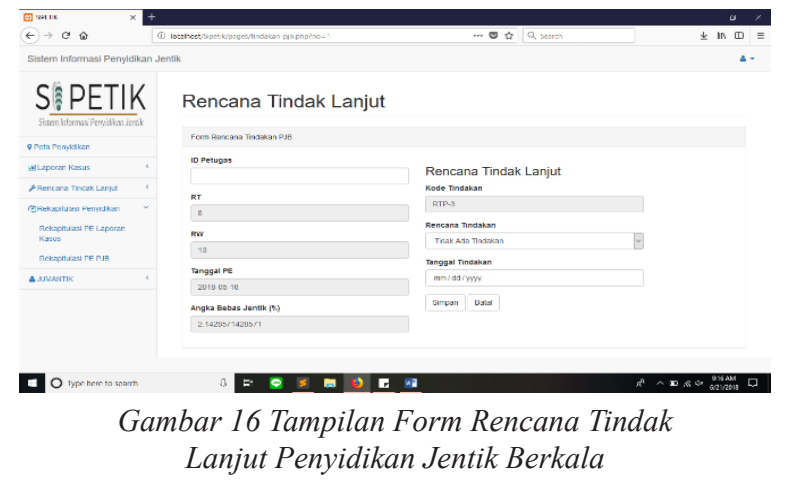

Gambar 16 merupakan tampilan form input data rencana tindakan penyidikan jentik berkala. Halaman ini merupakan halaman lanjutan yang berasal dari halaman laporan angka bebas jentik. Sama seperti pada halaman rencana tindak lanjut penyidikan laporan kasus, halaman ini berisi form input untuk membuat data baru. Terdapat dua button yang digunakan untuk menyimpan data dan membatalkan pengisian data

\section{F. Pengujian Sistem}

Pengujian aplikasi menggunakan pengujian Alpha dengan cara menguji langsung kepada pengguna akhir untuk mengetahui fungsi yang ditampilkan sudah berjalan dengan baik dan sesuai 
dengan kebutuhannya. Pengujian menggunakan 2 butir poin pengujian sebagai landasan pengujiannya yaitu dari sisi konten dan fungsionalitas [7].

Berdasarkan pengujian yang dilakukan bersama dengan Ibu Guspi selaku petugas puskesmas yang bertugas untuk kasus Demam berdarah dan kegiatan PE pada periode tahun 2018, aplikasi yang dirancang dapat diterima. Aplikasi telah memenuhi fungsifungsi yang dibutuhkan baik yang berbasis Android maupun aplikasi pendukung yang berbasis website. Diharapkan aplikasi ini dapat memberikan manfaat kepada pihak terkait.

\section{SIMPULAN}

Berdasarkan hasil penelitian yang dilakukan, sistem informasi geografis penyidikan epidemiologi jentik nyamuk berbasis android dapat disimpulkaan, bahwa: Model pengembangan prototyping yang digunakan cocok digunakan didalam penelitian ini. Apabila menggunakan model pengembangan lain dikhawatirkan tidak dapat berjalan dengan baik karena pengguna akhir kurang memahami kebutuhan system; Lokasi hasil penyidikan epidemiologi diperlukan sebagai acuan petugas puskesmas untuk menentukan area endemic; Pencatatan data penyidikan yang dilakukan oleh kader jumantik secara online dapat mempercepat petugas puskesmas memperoleh data hasil penyidikan; Presentase angka bebas jentik ditampilkan secara otomatis, petugas puskesmas tidak memerlukan perhitungan secara manual; dan Data laporan kasus dapat langsung diterima oleh kader jumantik sehingga kegiatan penyidikan laporan kasus dapat langsung dilakukan.

\section{DAFTAR RUJUKAN}

[1] "Bekasi kota dalam angka 2017," [Online]. Available: https://bekasikota.bps.go.id/website/pdf_publikasi/ Kota-Bekasi-Dalam-Angka-2017.pdf. [Accessed 7 November 2017].
[2] "Penyidikan Epidemiologi," Buku Saku UPTD Puskesmas Wisma Jaya.

[3] E. Prahasta, in Sistem Informasi Geografis: Konsep-konsep Dasar (Perspektif Geodesi \& Geomatika), Bandung, Informatika, 2009, pp. 118.

[4] J. Istiyanto, Pemrograman Smartphone Menggunakan SDK Android dan Hacking Android, Yogyakarta, Graha Ilmu, 2013, pp. 4-11, 30-31

[5] "Mengenal Android Studio," [Online]. Available: https:// developer.android.com/studio/intro/index.html?hl=id. [Accessed 20 Maret 2018].

[6] R. A. Shalahuddin, Rekayasa Perangkat Lunak Terstruktur dan Berorientasi Objek, Bandung, Informatika, 2015, pp. 50-51, 26-30.

[7] R. S. Pressman, Software Engineering A Practitioner's Approach: Seventh Edition, New York, Higher Education, 2010, pp. 43-44, 530-531.

[8] T. K. A. S. A. Ali Ridho Barakbah, Logika dan Algoritma, Politeknik Elektronika Negeri Surabaya, 2013, pp. 1923.

[9] T. Welling.L, PHP and MySQL Web Development" fifth Edition, Developer's Library, 2016, pp. 2, 3.

[10] “About Google Maps," Google, [Online]. Available: https://www.google.com/maps/about/ [Accessed 5 Januari 2018].

[11] J. Simarmata, Rekayasa Perangkat Lunak, Yogyakarta, ANDI, 2010, p. 321.

[12] M. S. C. H. G. K. Martina Seidl, UML @ Classroom: an Introduction object oriented modelling, Springer International Publishing AG, 2014, pp. 11-13, 23-32, 141-150, 49-60, 107-112.

[13] N. Alfianika, Metode penelitian pengajaran bahasa Indonesia, Yogyakarta, Deepublish , 2015, pp. 22-25 